\title{
Studies on the Urinary Excretion of the Catecholamines and their Metabolites in Patients with Glucocorticoids Therapy
}

\author{
Shigezi IKEDA \\ First Department of Medicine, Kyoto Prefectural University of Medicine, Kyoto \\ (Director : Professor Hideo Yoshida, M.D.)
}

Wurtman et al. demonstrated in rats that low doses of glucocorticoid depress the endogenous steroid secretion in the adrenal sinusoid, consequently inhibit the activity of phenylethanolamine $-\mathrm{N}$ - methyltransferase and decrease the content of adrenaline in the adrenal medulla. They also suggested that patients who have been maintained chronically on low doses of glucocorticoid may show an abnormality in their ability to synthesize adrenaline. In this paper, the author attempted to observe the urinary excretion of catecholamines and their metabolites in patients on steroid therapy and to determine whether Wurtman's suggestion may be applied clinically.

Forty patients who were receiving 1.0 to $4.0 \mathrm{mg}$ betamethasone daily and twenty who had been absolutely free from steroid for at least one year, were studied. Urine specimens were assayed for free catecholamines as described by Sugano (1965) with minor modifications, total metanephrine \& total normetanephrine by the method of Häggendal (1962), vanillyl manderic acid by the method of Sandler \& Ruthoven (1959), homovanillic acid by the method of Sankoff \& Sourkes (1963) and 17-OHCS by the method of Porter-Silber after hydrolysis with $\beta$-glucuronidase and extraction with chloroform.

(1) Forty patients who had been receiving steroid were newly loaded equally with $4.0 \mathrm{mg}$ betamethasone daily for 4 days. Between the steroid-loaded patients and the steroid-free patients, no significant differences in the daily urinary excretions of catecholamines and their metabolites were detected.

(2) In thirty-six patients during the course of steroid therapy, urine was collected during the day between 7:00 A.M. and 10:00 P.M. and again between 10:00 P.M. and 7:00 A.M. the next morning. (a) The relationship between urinary catecholamine excretion and urinary 17-OHCS excretion, (b) the relationship between the length of the steroid therapy and urinary excretion of catecholamines and their metabolites and (c) the relationship between the total doses of steroid and the urinary excretion of catecholamines and their metabolites were studied respectively. (a) In the steroid treated patients, decreased urinary 17-OHCS excretions was observed. But there was no quantitative correlation between urinary 17-OHCS and urinary catecholamines. (b) Three groups of patients were compared. The first group included the patients who had been receiving steroid for less than one month. The second group included the patients kept on steroid therapy for more than one month. The third were the steroid-free control group. In comparison with the control group, the urinary excretion rate of adrenaline 
increased in the first group and decreased in the second group. There were no significant differences in the urinary excretions of noradrenaline in all three groups. Therefore the $\mathrm{A} / \mathrm{A}+\mathrm{NA}$ ratio was elevated in the first group and lowered in the second group. In the study of urinary catecholamine metabolite excretion, there were no significant differences in the three groups. (c) Regarding the total doses of steroid, the patients were divided into four groups: the first group with the total steroid under $50 \mathrm{mg}$, the second group, $50 \mathrm{mg}$ to $100 \mathrm{mg}$, the third group, over $100 \mathrm{mg}$ and the fourth group, the steroid-free control group. In contrast to the control group, urinary adrenaline was increased in the first group and decreased in the second and the third group. There were no remarkable differences, in the urinary noradrenaline and the catecholamine metabolites excretion.

(3) Three inpatients were treated with betamethasone, $3.0 \mathrm{mg}$ daily for the first 21 days, $2.0 \mathrm{mg}$ daily for the next 14 days and maintained on $1.5 \mathrm{mg}$ daily after the $35 \mathrm{th}$ day. The urinary adrenaline excretion increased in the first week after the beginning of the steroid administration and decreased in the sixthweek. The urinary noradrenaline excretion increased slightly in the first week and returned to the pre- steroid administration level. The $\mathrm{A} / \mathrm{A}+\mathrm{NA}$ ratio was elevated in the urine collection of the first week and lowered in the urine collection of the sixth week.

(4) Steroid treatment with betamethasone $3.0 \mathrm{mg}$ daily was continued for 42 days in 7 patients and then interrupted for 4 days. The recovery of urinary 17-OHCS and the response of the urinary catecholamines during the interruption were studied. Before the interruption, urinary 17-OHCS and urinary adrenaline were significantly decreased in comparison with the control group. Recovery to the normal range of urinary 17OHCS was seen three or four days after the interruption but no sign of recovery of the urinary adrenaline was found during the interruption.

The author obtained the above mentioned results attempting to observe clinically the adrenal cortico-medullary interrelationship on the basis of Wurtman's suggestion. After some discussion with considerations of the data in the literautre, the following conclusions were formulated. The theory introduced by Wurtman and his co-workers appears to be applied to human beings clinically. Although the modes of action of the interrelationship between the adrenal cortex and adrenal medulla can not yet definitely clarified, the following points may be speculated. Though the adrenocortical activity will be promptly suppressed with the beginning of steroid administration, the adrenomedullary secretion will be initially facilitated through undetermined mechanisms. When steroid administration is continued further, then the medullary activity will be suppressed as described by Wurtman et al. With the withdrawal of steroids, the adrenocortical recovery will ordinarily occur within three to four days, but there appears to be no sign of the recovery of the urinary adrenaline excretion. There seems to be some lag between the recovery of the adrenocortex and that of adrenomedulla.

(See $-1200 \sim 1217$ )

Vol. 50 No. 8 


\title{
副腎皮質糖質ステロイド投与中患者に於ける，カテコー ルアミン及びその代謝産物の尿中排泄に関する研究
}

\author{
京都府立医科大学第一内科学教室（指導: 吉田秀雄教授） \\ 池田滋司
}

（昭和 49 年 4 月 23 日受付）

糖質ステロイド投与中患者に於ける副腎髄質の状態を尿中カテコールアミン及びその代謝産物の測定 を通じて観察した．ステロイドを投与すると尿中 17-OHCS は急速に抑制されるが，尿中アドレナリン は一且上昇する期間を経て後低下するという二相性の反応を示す．尿中ノルアドレナリン，カテコラミ ン代謝産物の変化は僅少であつた，又ステロイド中止後，尿中 17-OHCS は $3 \sim 4$ 日で恢復するが，ア ドレナリンには恢復の徴候はなかつた。

哺乳類の副腎は皮質と喵道質に分けられるが，個体発生学的にみると，前者は coelomic mesothelium そ由 来し, 後者は neuroectoderm に由来すると言う異質の起源を有して居る. 系統発生学的にも, 円口類の如 き低級脊椎動物では, 此の両部は互いに独立の器官として並存しており, 爬虫類, 鳥類と進化の段階を追つ て接近し, やがて哺乳類に於て, 副腎と言う単一の臓器を作る。哺乳類副婜の皮質及び前造質は, 一つの藏器 を構成するとは言うものの, 他の藏器の皮質一旤質の関係に見られる如き,一つの機能の系統の各段階を両 部が各々受持つというのでなく，副腎に於ては，一方は間脳下垂体一副腎皮質系の，他方は交感神経一副腎 髄質系の各ターミナルをなしていて, 別個の機能系に属している，その様に哺乳類副腎は異質の両部分より なりたつているのであるが, 両者間には密接な血管系の連絡が存在し，いわゆる皮質一搉質間門脈系を形作 つて居る. 此の様な副腎皮質と嗔質の特殊な解剖学的構造は, 両者間の機能的な相互連携を強く窅わせるも のである.

1950年代初め，Shepherd \& West $(1951)^{1)}$ やCoupland $(1953)^{2)}$ は皮質ホルモンが副腎佮有質中のノルア ドレナリン (NA と略) のアドレナリン (A と略)への N-メチル化に関係する因子である事を明らかにして, 此の深題の研究に先鞭をつけた。 そして1960年代後半に入つて Wurtman \& Axelrod ${ }^{32 \sim 8)}$ 等は下垂体剔出 ットを用いての一連の実験で，NA ょりAへの転化に作用する酥素 phenylethanolamine-N-methyltransferase (PNMT) の蛋白合成が高濃度の糖質ステロイド（CS と略）に依存する事を証明した，此の証明を 通じて, 彼等は哺乳類副腎蹃質が皮質組織の被覆の中で存在し, 副腎内門脈流を経由して高濃度の CS を 含む血流に灌流されると言う解剖学的位置関係の意義が説明され, 又此の関係を通じて, 下垂体一副腎皮質 系がA生合成をコントロールすると考えている，尚彼等は又，「正常ラットに低い生理的量の CS を与えた 場合，下垂体副腎皮質系は抑制されて，副腎皮質は萎縮する，その様な処置では末梢の target organ では 血流内 CS は外因性 CS 亿維持されて副腎皮質不全の徴候は示さないが, 副腎静脈内 CS ほ低下する. 少 量の CS 投与を反復すると髄質内 PNMT 活性は著明に低下し, A合成は低下する. 從つて臨床的に維持 量の CS により長期治療を受ける患者で, A合成に異常があるか検討するのは興味深い。」と述べて居る.

Hench \& Kendall (1949) のリウマチ性疾患に対する CS の使用報告以来, 年を追つて CS の治療医学に 
占める役割は拡大されつつあるが，反面 CS 使用による iatrogenic disorders としての問題点も增加しつ つある，とりわけ CS 投与と下垂体一副腎皮質系への抑制と言う問題は最も重要なものであり，CS 投与に よる下垂体一副腎皮質系抑制の副腎䯣質ホルモン产生への影響についての Wurtman 等の知見は興味深い. 動物実験に於る彼等の説は現在，間接的，直接的に追試，傍証を受け，客観性を以つて受け容れられて居る が，尚人体に於る臨床的な意義付けに関しては推測の段階にある。著者は，入院中 CS 投与を受けて居る 患者中より実験目的に適合した症例を選択し，尿中カテコールアミン（CA と略）及びその代謝産物を測定 し，CS 投与と尿中 CA 排洺の観祭を行ない，得られた結果に若干の検討を加えてみた。

\section{実験対象並びに方法}

主として，京都府立医科大学第一内科及び松下病院第二内科に入院中の患者より対象を求めた．1.0 $\mathrm{mg} \sim$ $4.0 \mathrm{mg}$ の betamethasone 投与中の患者より，20歳以上，45歳末満の年齢帯にあり，臨床的に，可及的自覚 的，他覚的所見の緩解した者を選択して被検者とした。一方 CS を少なくとも 1 年以内使用されて居ない事 が明確で，上記年齢带にあり，同様臨床症状の消失した入院患者より20名（男子10名，女子10名）在選んで 対照者とした，採尿前24時間より採尿中を通じて，被検者群に於ては betamethasone のみの投与を行ない， 対象群では完全に薬剤の投与を中止した．採尿中は全ての検查手技を避け，午前 7 時より午後 10 時までの間 は飲食, 入浴, 運動乞の他に特別の制限を設けず, 午後 10 時より翌午前 7 時までは用便以外は就寝, 熟睡す る様はかつた。尚翌朝検体採取に当つて, 各人に問㟝, 前夜睡眠障害を訴光る者については, その尿を検体 より除いた。尿は予め $6 \mathrm{~N}-\mathrm{HCl}, 15 \mathrm{ml}$ を投入した蓄尿ビンに蓄尿せしめ, 冷暗所に保存した。検体は翌朝

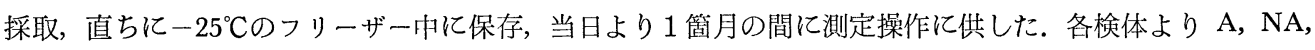
メタネフリン (Mと略), ノルメタネフリン (NM と略), バニールマンデル酸 (VMA と略), ホモバニ リール酸 (HVA と略), 17-OHCS を測定した。

1 ）尿中遊離型 CA の測定は敬野 $\left.(1965)^{9}\right)$ の方法を一部改変して行なつた。即ち検体尿 $40 \mathrm{ml}$ を酸水 解を行なわずに，直ちに $\mathrm{pH} 8.5$ とし，アルミナ $1.5 \mathrm{~g}$ を径 $1.34 \mathrm{~cm}$ のカラムとした物に通じ，以下原 法同様に酢酸浴出，Amberlite GG-50 カラムで精製した後，THI 法による螢光測定を行なつた。唯 A, NA 分離定量により優れている事を考虑して, 酸化反応過程を $\mathrm{pH} 3.5$ と $\mathrm{pH} 6.5$ 亿於る $\mathrm{pH}$-differential method を使用した. 即ち, 検体を $\mathrm{pH} 3.5$ と $\mathrm{pH} 6.5$ の 2 系列に分け, 一検体每に内部規準液, 酸化型 サンプルブランクを使用, 反応方法を菅野法と同一手順で行ない, 八木式螢光光度計 UM 型を用い, 一次 フィルター UV- $\mathrm{O}_{2}$, 二次フィルター Fl- $\mathrm{B}_{2}$, 紫外線遮断フィルターとして UV-V $\mathrm{V}_{2}$ 装着して測定した. 回

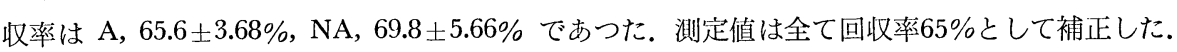

2 ）尿中総M及び総 NM は Häggendal $(1962)^{10)}$ 法によつた。螢光測定は, 八木式螢光光度計 UM 型 を用い, differential filter method を行なつた. 一次フィルターAKAIF $370 \mathrm{~m} \mu$, 二次フィルター AKAIF

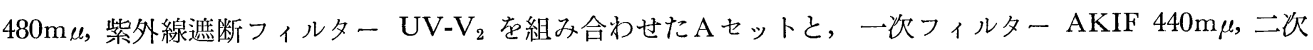

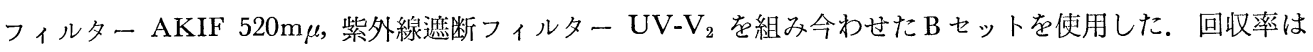
M, 88.7 $\pm 8.98 \%, N M, 89.9 \pm 10.1 \%$ であつた。測定值は全て回収率90\%として補正した.

3 ）尿中 VMA 測定はS Sandler (1959) ${ }^{11)}$ 法によつた。 回収率は $82.3 \pm 4.55 \%$ であつた。測定値は全て 回収率 $80 \%$ として補正した。

4) 尿中 HVA の測定は Sankoff \& Sourkes $(1963)^{12)}$ 法によつた. 回収率は $35 \%$ として補正した.

5 ) 尿中 17-OHCS 测定は臟器性 $\beta$-glucuronidase 飞より, 24時間水解後, クロロホルム抽出, PorterSilber 法によつた。習慣により回収率補正はしていない.

\section{結果}

（1）一定の CS 負荷を与えた場合の尿中 CA 及び CA 代謝産物, 17-OHCS の排泄について.

現在 CS 治療を受けつつある40例の入院患者に対し, 更めて一律に 4 日間, $4.0 \mathrm{mg}$ betamethasone を 
投与し，副腎皮質の抑制を強化した上で，4 日目に採尿した。20例の CS 非使用者との間で，17-OHCS， A，NA，M，NM，VMA，HVA の24時間尿中排泄量を比較する，尿中 17-OHCS は被検例では $1.34 \pm 1.35$ $\mathrm{mg} /$ 日，非使用例では $3.43 \pm 1.04 \mathrm{mg} /$ 日であり，被検例では外因性 CS による下垂体一副腎皮質系の抑制 が明らかである。他方尿中 CA 及びその代謝産物については両者間に有意の差がない，唯被検例では， HVA を除いて標準偏差が全て非使用例の 2 倍となる事よりみれば，CS 投与は CA 産生分泌に対して何ら かの影響を有し，その個人差を增すとも考学うるが，単純に副婜皮質抑制が交感神経一副腎髄質系に一方向 の変化を与えるとは考光難い，(Table 1)

Table 1. Urinary excretion of catecholamines and their metabolites in patients with and without glucocorticoid therapy.

\begin{tabular}{l|c|c}
\hline & without CS. & with CS. \\
\hline \hline 17-OHCS** & $3.43 \pm 1.04$ & $1.34 \pm 1.35$ \\
Adrenaline* & $5.76 \pm 1.44$ & $6.26 \pm 3.59$ \\
Noradrenaline* & $30.4 \pm 10.3$ & $32.4 \pm 23.4$ \\
Metanephrine* & $128 \pm 35.4$ & $126 \pm 70.2$ \\
Normetanephrine* & $186 \pm 49.7$ & $179 \pm 98.5$ \\
Vanillyl mandelic AC.** & $3.95 \pm 1.03$ & $4.41 \pm 2.30$ \\
Homovanillic AG.** & $8.62 \pm 2.70$ & $8.01 \pm 3.11$ \\
& $(20$ cases $)$ & $(40$ cases $)$ \\
\hline
\end{tabular}

$* \mu \mathrm{g}$ per day. $\quad * * \mathrm{mg}$ per day.

（2） CS 治療途上にある患者の尿中 CA 及び CA 代謝産物，17-OHCS 排泄について. 特に就床安静時 に於ける観察

CS 分泌は日常生活に於る如き体位変換, 入浴, 映画鑑賞等の生理的範囲内の精神的・肉体的活動によつ ても容易に変動を受ける事が認められて居る，その様に CA の分泌速度か湾化する際には又，GA の不活 性化の機構の面にも複雑な動きを予想するのが順当である. 従つて尿中 GA 及びその代謝産物は排泄量の みならず，その pattern も非特異的，生理的な因子により修飾される事が予想される。人体を対象として

Fig. 1-1. Urinary 17-OHCS and urinary adrenaline during the steroid therapy.
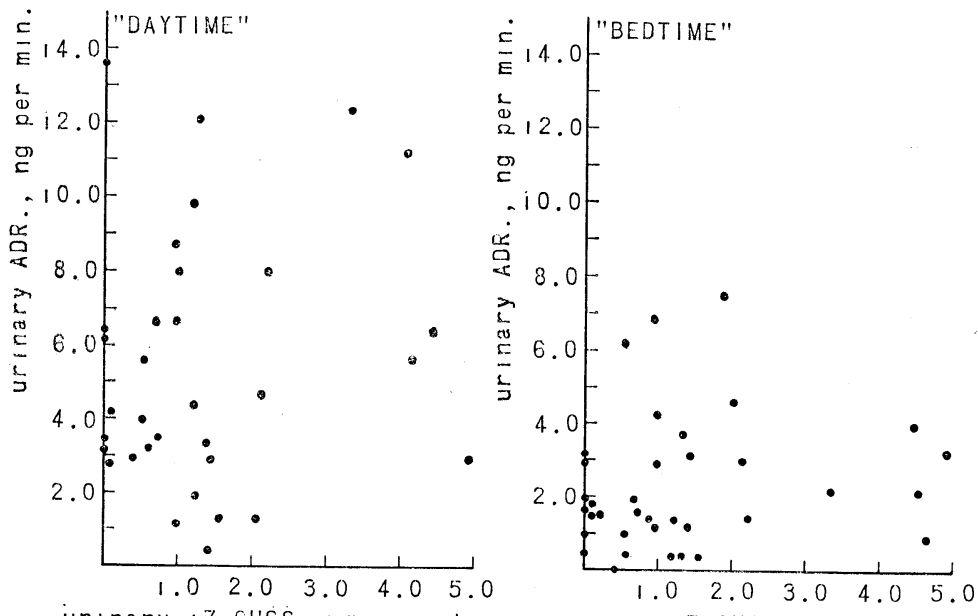

urinary 17-Otics, mg per day.

urinary 17 - OHCS, mg per day. 
Fig. 1-2. Urinary17-OHCS and urinary noradrenaline during the steroid therapy

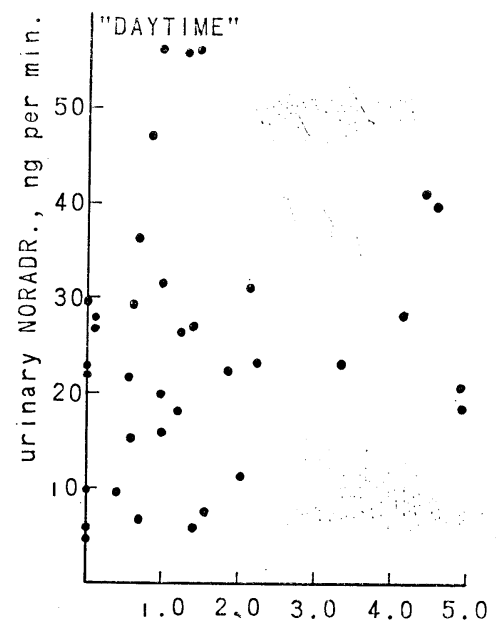

urinary 17-OHCS, mg per day.

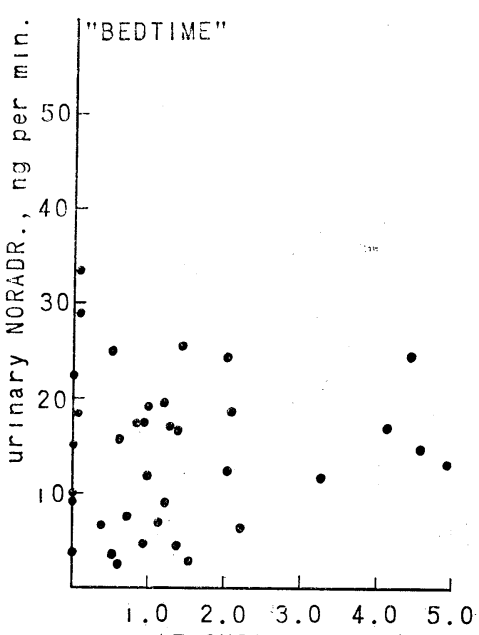

urinary i7-OHCS, mg per day.

Fig. 1-3. Urinary 17-OHCS and the urinary adr. to adr. + norad. ratio during the steroid therapy

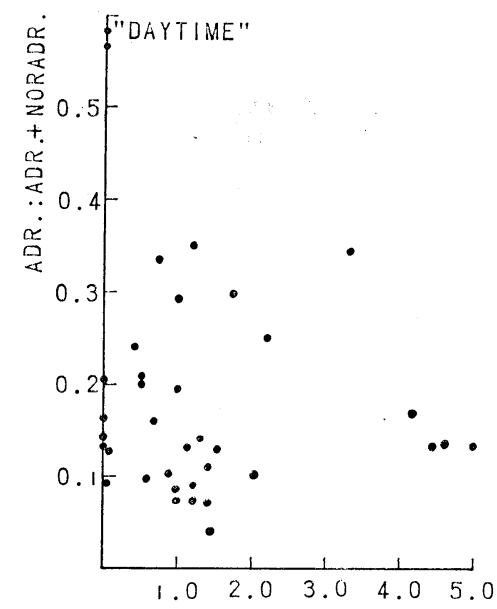

urinary i7-OHCS, mg per day.

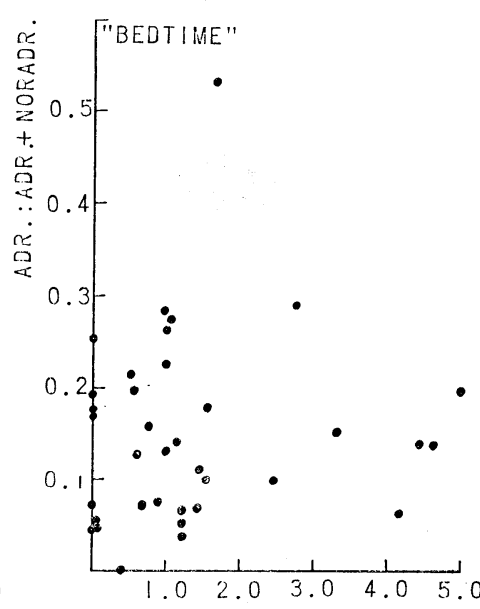

urinary 17 -OHCS, mg per day.

尿中 GA 排泄の測定を試みる場合には，各被検者の状態を実験目標に沿う様な条件の元に一律に置く事が 理想的であるが，一般入院患者より症例を得る様な場合には，必らずしも容易な事ではない．所で今起床時 及び就寝時分割尿を採取する事により, 就寝中と言う比較的限定された条件下で検体を得る事が出来ると共 に，他に副腎髄質一交感神経系機能の亢進した時間带と抑制された時間帯とに於る CA 及び代謝産物の尿 中排泄を比較観察する事も可能となる。

採尿を午前 7 時より午後 10 時までの起床時と午後 10 時より翌朝 7 時までの就寝時に分けて行ない，CS 使 用36例，非使用20例について，上記各時間帯に於ける A, NA, M, NM, VMA 尿中排泄量と 17-OHCS 24 時間尿中排泄量を測定した。

a）CS 使用者に於ける，尿中 17-OHCS と尿中 CA 排泄 
採尿時の副腎皮質の分泌量を尿中 17-OHCS で推定し，尿中 CA 排泄量よりみた副腎檤質一交感神経系 機能との関係を検討してみると，CS 使用者では平均して尿中 17-OHCS の低下をみるが，その際尿中 CA との間には殆ど一定の関係は認めなかつた，換言すれば，人体の副腎皮質と撾質間に機能の相互関係がある と仮定しても，相互の分泌が量的な相関関係を示す様な一方向の緻密な連携ではないと考学うる。（Fig. 1-1， $1-2,1-3)$.

b ） CS 使用期間と尿中 CA 及びその代謝産物排泄量 $\mathrm{b}-1$ ）起床時尿中 $\mathrm{A}$ 排泄.

Fig. 2-1.の如く縦軸に尿中 A 分時排泄量, 横軸に CS 使用日数を取り, 被検各例の測定值を plot すると,

Fig. 2-1. The duration of the steroids therapy and urinary adrenaline in daytime.

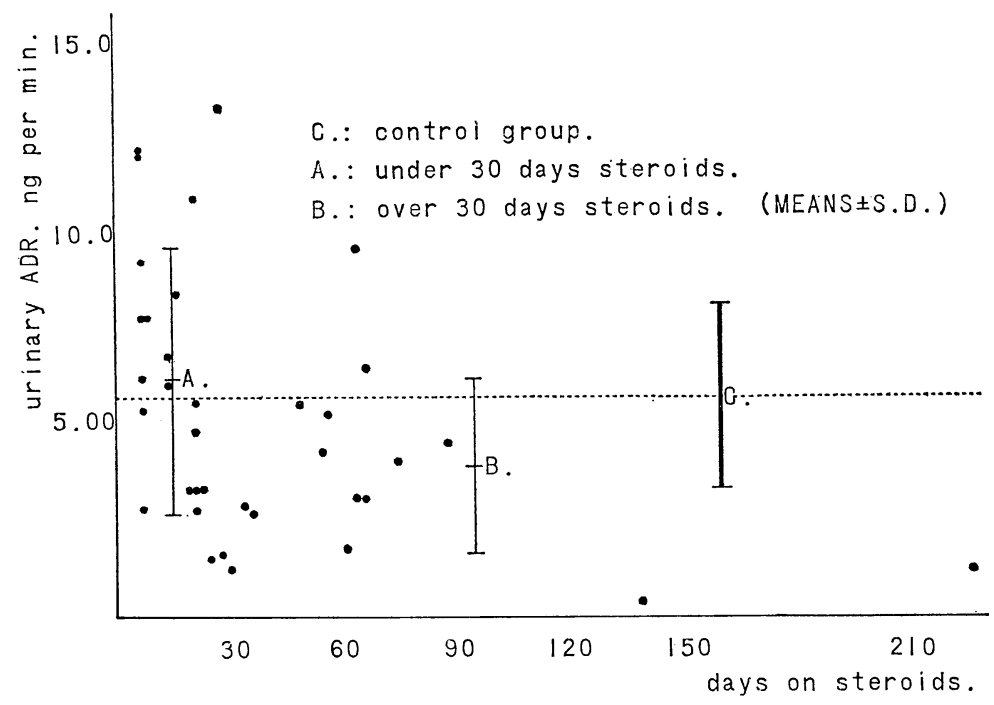

使用期間 30 日末満例では非使用例対照群の平均值の周囲に同様に分布するが，30日以上例では14例中 2 例を 除く12例乃対照群平均值の下方に分布する. 使用期間 30 日末満群, 30日以上群, 非使用対照群を設定し, 三 者を対比させて検討すると, 夫々 $6.29 \pm 3.55 \mathrm{ng} /$ 分, $4.00 \pm 2.99 \mathrm{ng} /$ 分, $5.82 \pm 2.41 \mathrm{ng} /$ 分となり, 対照群との 間に使用 30 日末満群で上昇の傾向は認めるが有意ではなく，30日以上使用群では有意の低下を認めた。

b - 2) 起床時尿中 NA 排泄. (Fig. 2-2.)

使用期閒 30 日末満群，同 30 日以上群，非使用対照群の起床時尿中 NA 排泄は夫久 $29.5 \pm 23.0 \mathrm{ng} /$ 分， 24.7 $\pm 7.69 \mathrm{ng} /$ 分， $25.5 \pm 3.80 \mathrm{ng} /$ 分であり，使用期間に関係なく NA 排泄は不変である. 唯使用期間 30 日末満群 では，30日以上及び非使用対照群に比較して標準偏差が極めて大であり, 尿中排泄量に個人差か開くと考党 られる。

b-3）就床時尿中 A排泄. (Fig. 2-3.)

使用期間 30 日末漛群 $3.03 \pm 1.08 \mathrm{ng} /$ 分, 30 日以上使用群 $0.986 \pm 0.611 \mathrm{ng} /$ 分, 非使用対照群 $1.90 \pm 0.693 \mathrm{ng} /$ 分となり，非使用対照群に比し，30日未満群では有意の上昇を，30日以上使用群では有意の低下を認めた。

b-4）就床時尿中 NA 排泄.（Fig. 2-4.)

使用斯間 30 日未欂群 $14.0 \pm 7.40 \mathrm{ng} /$ 分， 30 日以上群 $13.2 \pm 10.0 \mathrm{ng}$ /分，非使用対照群 $14.0 \pm 6.44 \mathrm{ng} /$ 分で 3 群共, 相互に有意の差を認めない。

$\mathrm{b}-5$ ）起床時尿申 $\mathrm{A} / \mathrm{A}+\mathrm{NA}$ 比について. (Fig. 2-5.) 
Fig. 2-2. The duration of the steroids therapy and urinary noradrenaline in daytime.

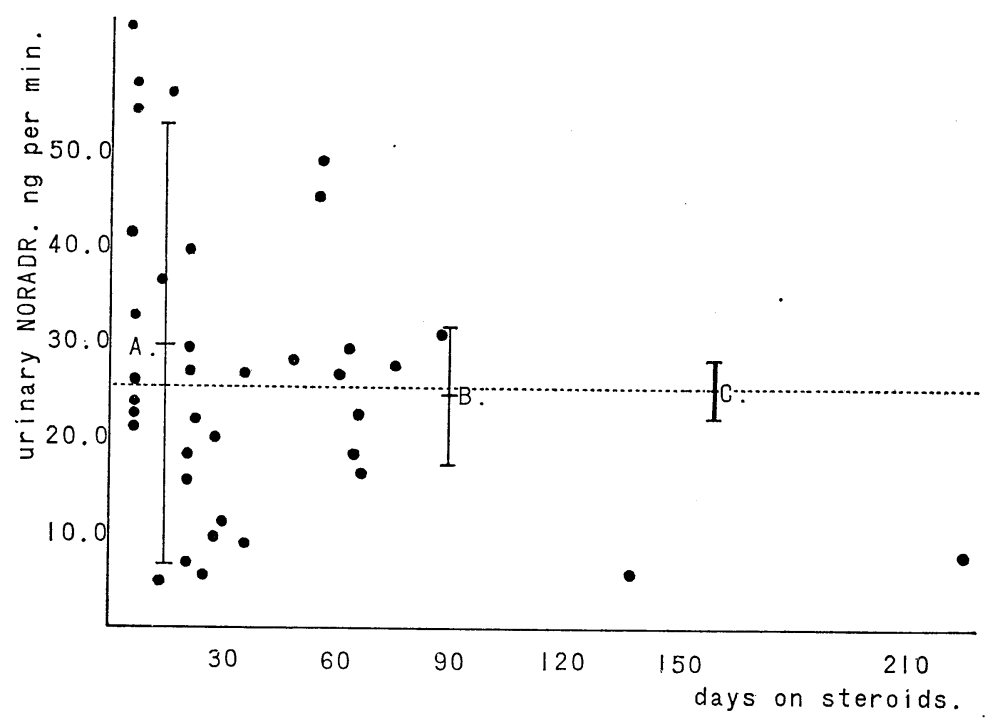

Fig. 2-3. The duration of the steroids therapy and urinary adrenaline in bedtime.

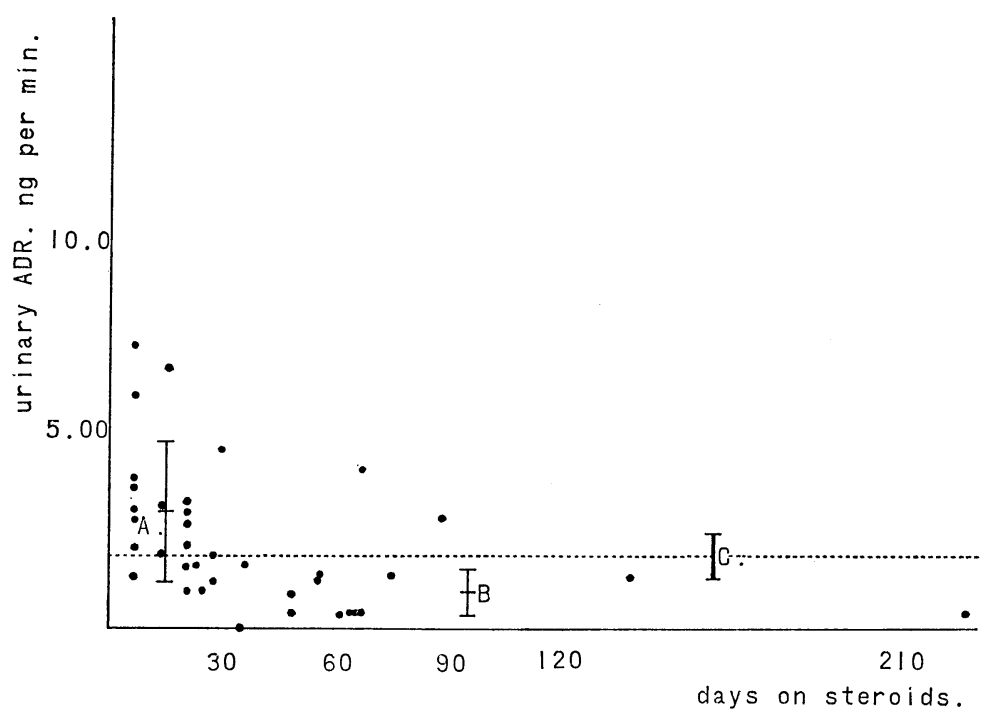

尿中 CA の内， Aの占める割!合いを CS 投与期間との関連で検討してみると， GS 使用 30 日未渾群 21.4 $\pm 12.1 \%$ ，使用 30 日以上群では $14.9 \pm 5.66 \%$, 非使用対照群では $18.2 \pm 6.93 \%$ あり, 非使用対照群との間 に，使用 30 日未満群では上昇の傾向を，30日以上群では低下の傾向を取る.

b-6) 就床時 A/A+NA 比について. (Fig. 2-6.)

就床時に於ては, 該比は CS 使用30日未満群では $18.8 \pm 3.60 \%$, 使用 30 日以上群では $6.62 \pm 3.61 \%$, 非使 用対照群では $10.8 \pm 2.82 \%$ あり, 非使用対照群との間に, 使用 30 日未渾群では有意の上昇を，30日以上群 
Fig. 2-4. The duration of the steroids therapy and urinary noradrenaline in bedtime.

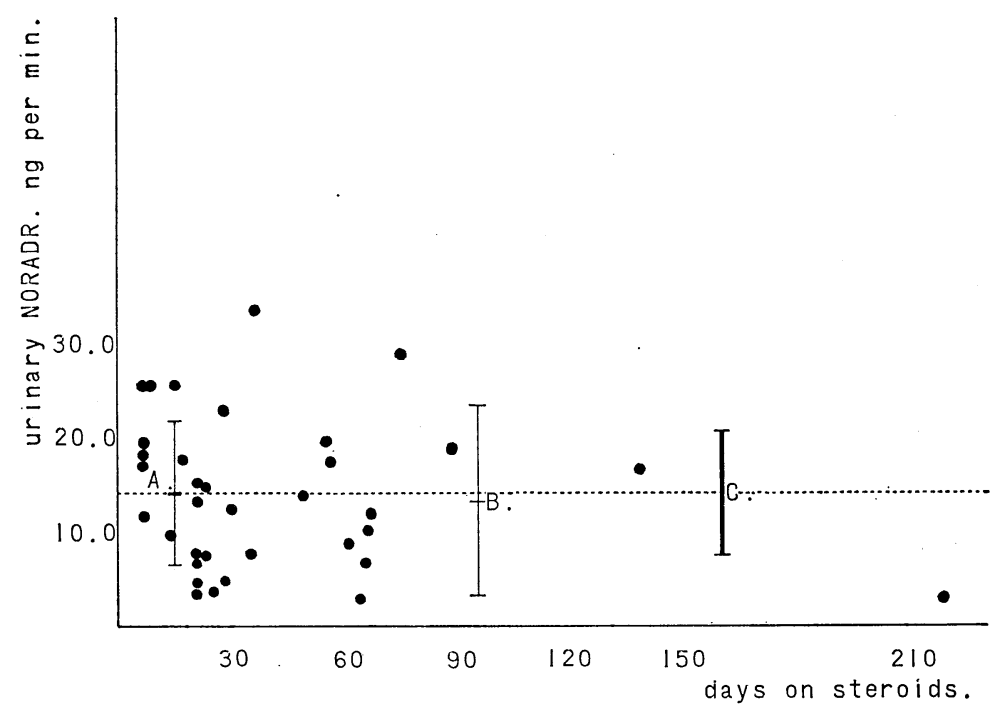

Fig. 2-5. Effects of the steroids therapy on the urinary adr. to adr. plus noradr. ratio in day time.

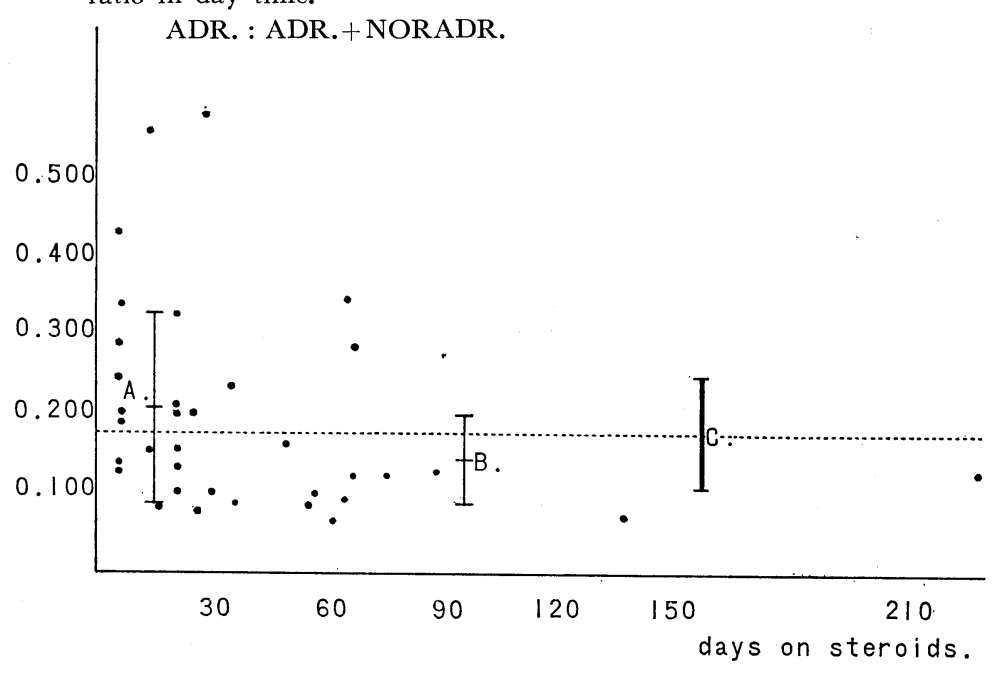

では有意の低下を認める.

b-7） CS 投与期間と尿中 GA 代謝産物排泄について. (Fig. 2-7.)

CA の主要代謝産物である M, NM, VMA の尿中排泄の状態を CS 投与期間の関係で検討すると, 起床 時M尿中排泄は, CS 30日未満治療群, 30日以上治療群, 非使用対照群の 3 群共殆ど差を認めない, 就床時 M尿中排泄は治療30日未満群では非使用対照群に比較して, 増加の傾向を, 30日以上使用群では低下の傾向 を取るが, その差は僅かであり有意ではない, 一方 NM 尿中排泄は起床時, 就床時共に全く差がない. 起 床時 VMA 排泄は，CS 30 日未満治療群で非使用対照群に比し，低下の傾向を取る. 30日以上使用群では 
Fig. 2-6. Effects of the steroids therapy on the urinary adr. to adr. plus noradr. ratio in bedtime.

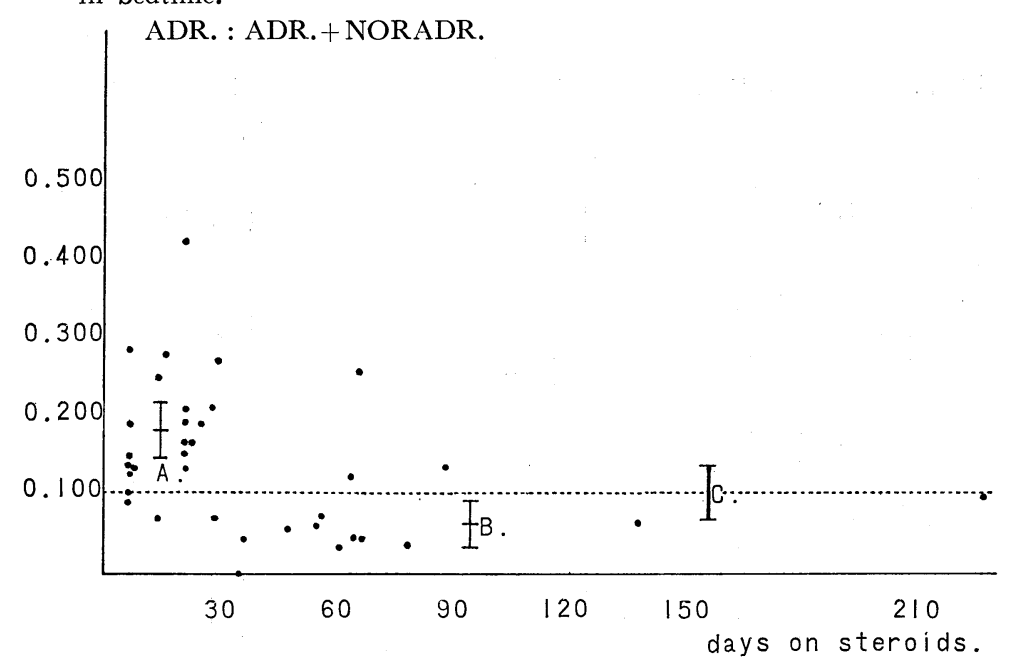

Fig. 2-7. Effects of the steroids therapy on the urinary catecholamine metabolites. (means \pm S.D.)

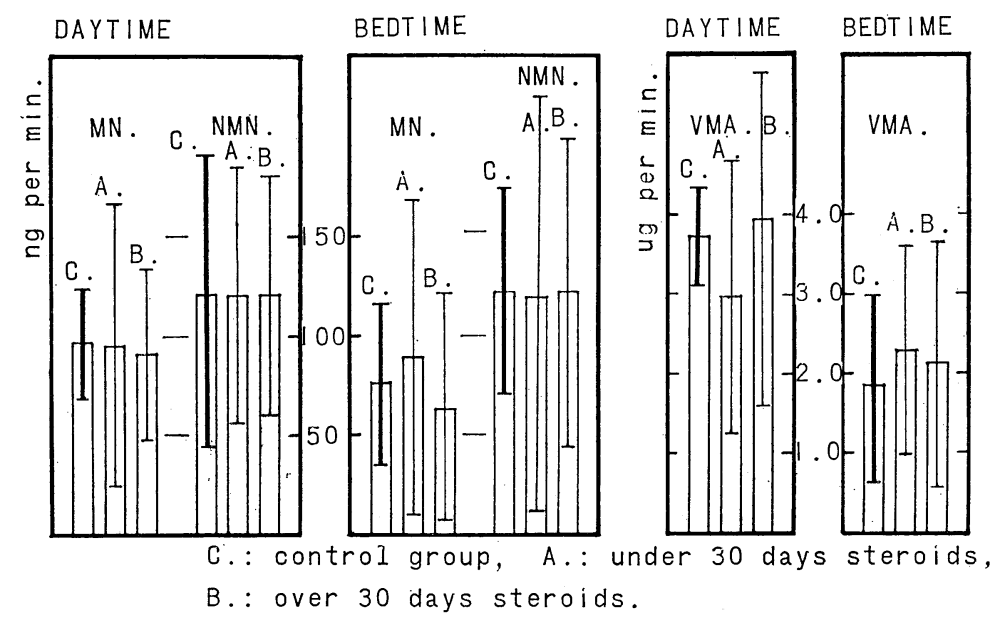

殆ど差を劲めない. 又起床時及び就床時を通じて, CS 使用例では, 非使用対照例に比較して, VMA 排泄 そ個人差が可成り大となる，他方就床時 VMA 尿中排泄は，CS 30日未満使用例，30日以上使用例共に， 非使用対照群に比し，やや上昇の傾向を取るが有意でない.

$\mathrm{b}-8$ ) 尿中 $\mathrm{M} / \mathrm{M}+\mathrm{NM}$ 比について. (Fig. 2-8.)

尿中に排澌される O-methylated amine 中Mの占める比率と CS 投与期間の関係を検討すると, 起床時

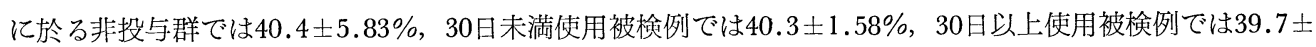
$2.90 \%$ で 3 群共差がない。就床時に於ては，非投与対照群では $37.9 \pm 9.59 \% ， 30$ 日未満使用群では43.3土 $1.82 \% ， 30$ 日以上使用群では33.0土2.70\%で，30日未満使用群では上昇の，30日以上使用群では低下の傾向 を見た。 
Fig. 2-8. Effects of the steroids therapy on the urinary catecholamine and their metabolites. (means \pm S.D.)

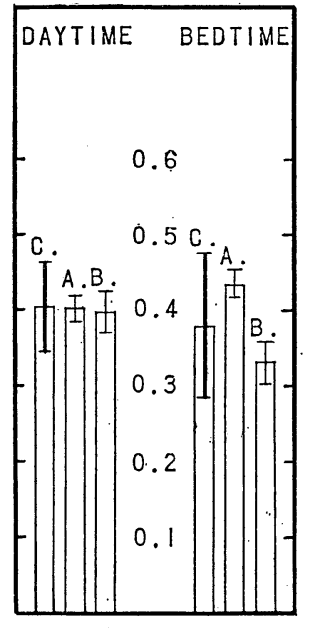

$M N$. : MN . NMN .

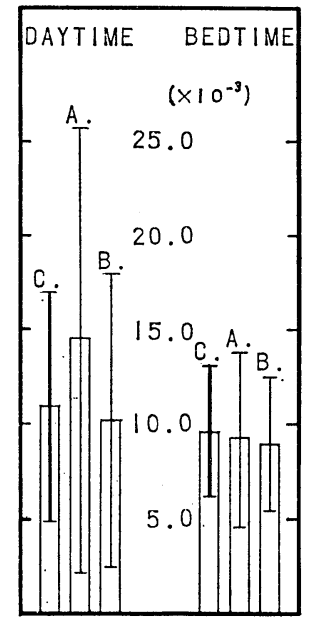

ADR + NORADR. : VMA.

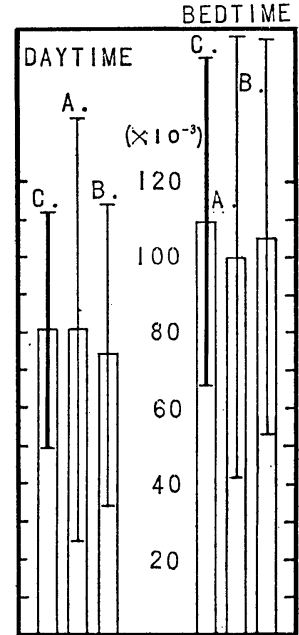

$M N$. $N M N$. : VMA .

C.: control group, A.: under 30 days steroids, B.: over 30 days steroids.

b-9）尿中 A+NA/VMA 比について. (Fig. 2-8.)

尿中遊離型 GA の排泄量を以つて，流血中に活性型で遊離される CA 量ないしは，交感神経系一副腎葡 質の activity を窺う手段として 利用される場合が多い ${ }^{13)}$ (Euler，1964). 所が CA 産生細胞に於て産生さ れる CA は，その一部が活性型の儘遊離されるに過ぎず，余剩に産生される組織中 CA は，大部分が細胞 内で in situ にミトコンドリアの monoamine oxydase (MAO) により deaminate され，尿中 VMA の 大部分の源となる ${ }^{14)}$ (I.J. Kopin, 1964). 從つて VMA 排泄量の測定は，交感神経一副腎髄質の activity と 言うより，むしろ CA 産生の大きさの示標としうると考えられている，そてで今遊離型 GA 尿中排泄量, VMA 尿中排浛量両者の比を取つて，CA の産生と遊離の間の balance を考省てみる. 起床時採尿に於て A + NA/VMA 比は CS 30日未満投与例で $14.5 \pm 11.2\left(\times 10^{-3}\right) ， 30$ 日以上投与例は $10.2 \pm 7.72\left(\times 10^{-3}\right)$ であり，非投与対照例では10.9 $06.00\left(\times 10^{-3}\right)$ である. 30 日未満投与例では，やや上昇の傾向を示すが， 推計学的には有意でない. 就床時に於ては，30日未満投与群では9.17士4.59 $\left(\times 10^{-3}\right)$, 投与30日以上群で

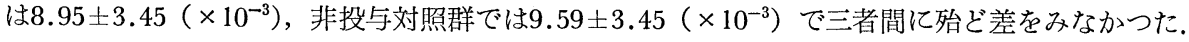

$\mathrm{b}$-10）尿中 $\mathrm{M}+\mathrm{NM} / \mathrm{VMA}$ 比について（Fig. 2-8.)

血流中に遊離される活性型 GA の代謝に対し， catechol-0-methyl transferase (COMT) が重要な役割 を占める. 形成された 0-methylated amine の尿中排泄量は CA 分泌量を反映するものとして，前項と同 様 M+NM/VMA 比を以つて，CA の組織産生量と遊離との間の balance を考えてみる. 起床時該比は,

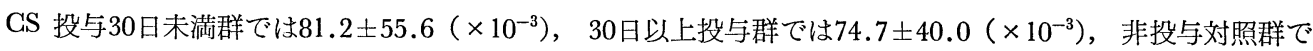
は80.6士31.6 $\left(\times 10^{-3}\right)$ で三者間に殆ど有意差を梕める事は出来なかつた。就床時については，投与30日未

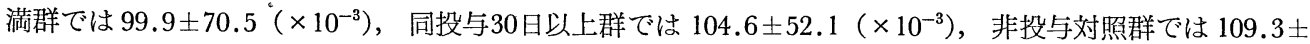
$43.4\left(\times 10^{-3}\right)$ となり，同じく三者共有意差がなかつた.

c） CS 使用総量と尿中 GA 及びその代謝産物について

CS 使用開始より採尿時迄の betamethasone 延投与 mg 数について, 50mg 以下の群（12名）を I 群，50 〜 100mgの群（12名）を II群，100mg以上の群（12名）をIII群として考える. 
Fig. 3-1. The total doses of steroids and the urinary catecholamine. (means \pm S.D.)

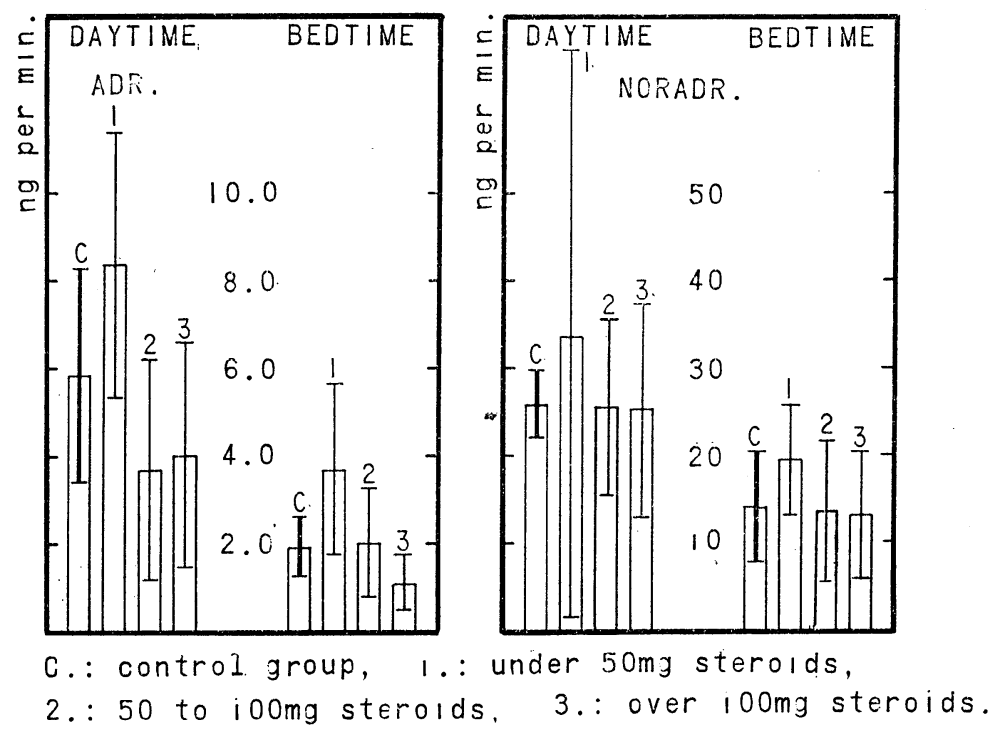

c - 1) 起床時A排泄について. (Fig. 3-1.)

起床時 $\mathrm{A}$ 排泄は I 群, $8.33 \pm 3.01 \mathrm{ng} /$ 分, II 群, $3.66 \pm 2.52 \mathrm{ng} /$ 分, III群, $4.02 \pm 2.54 \mathrm{ng} /$ 分, 非使用刘照群 $5.82 \pm 2.41 \mathrm{ng} /$ 分である. I 群では非使用群に対し有意の上昇を，II， III群では低下を示す.

$c-2)$ 就床時A 排泄について。 (Fig. 3-1.)

就床時に於ては，I群， $3.69 \pm 1.95 \mathrm{ng} /$ 分， II群， $1.98 \pm 1.22 \mathrm{ng} /$ 分， III群， $1.27 \pm 1.14 \mathrm{ng} /$ 分，非使用群， $1.90 \pm 0.693 \mathrm{ng} /$ 分となり，非使用対照群に比し，I群では有意の上昇を，I群は差なく， III群では低下を認 めた。

c - 3) 起床時 NA 排泄について。 (Fig. 3-1.)

起床時尿中 NA 排泄は I 群, $28.5 \pm 25.5 \mathrm{ng} /$ 分, II群, $23.2 \pm 9.77 \mathrm{ng} /$ 分, III群, $25.2 \pm 12.1 \mathrm{ng} /$ 分, 非使用 群, $25.5 \pm 3.80 \mathrm{ng} /$ 分, であり, 非使用対照群に対し, 三群共有意の差を認わなかつた。

c -4) 就床時尿中 NA 飞ついて. (Fig. 3-1.)

I 群に於ては $18.5 \pm 6.25 \mathrm{ng} /$ 分, II群では $13.6 \pm 7.93 \mathrm{ng} /$ 分, II群に於ては $13.1 \pm 7.42 \mathrm{ng} /$ 分, 非使用対照

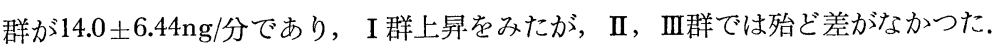

c-5 ) CS 使用総量と尿中 CA 代謝産物排泄について. (Fig. 3-2.)

尿中 $\mathrm{M}$ 排泄は起床時に於ては，CS 非使用例に対し，I群では上昇の傾向，II， III群では下降の傾向を取 り, 就床時に於ては, I 群上昇, II 群差なく, III群では下降傾向を取り大略尿中遊離型 $\mathrm{A}$ と同様の傾向であ るが，推計学的には有意でなかつた。尿中 NM 排泄は起床時, 就床時共 I, II, III群を通じて非投与対照 群に対して著明な差を認めなかつた。 尿中 VMA 排泄は I， II， III群共，非投与対照群との間に殆ど差を 認めなかつた。

以上小括すれば，尿中遊離型 CA は，CS 投与期間が短期間では Aの増加が，長期に亘ると Aの低下が 起り, NA 分泌は概して不変である. 従つて A/A + NA 比は CS 投与の早期に上昇し, 長期になると低下 する，因みに此の様な現象は夜間就寝時尿に，より明膫に認められ屋間尿では，やや不明膫であるが，前述 の如く，㡺間に於ては干渉因子が多く，夜間は干渉因子が減少するため，比較的実験条件が整うためと考え られる。 
Fig. 3-2. The total doses of steroids and the urinary catecholamine metabolites. (means \pm S.D.)
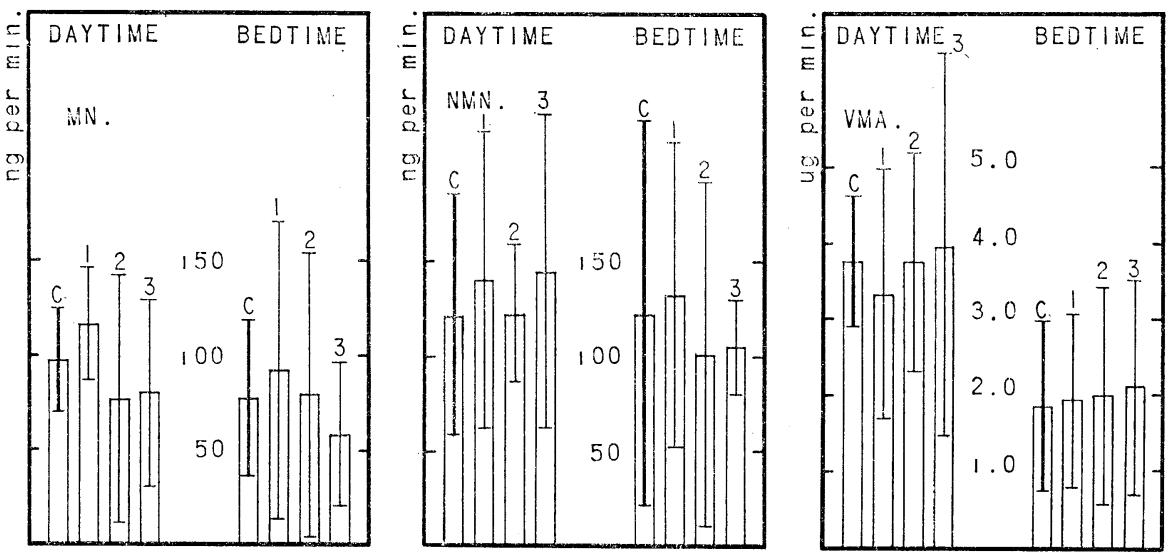

C.: control group, 1 : :

3.: over $100 \mathrm{mg}$ steroids.

0-methylated amine, VMA の尿中排泄と CS 投与期間の関係を検討すると，M，NM 尿中排泄は遊離 型 $\mathrm{A} ， \mathrm{NA}$ を， $\mathrm{M} / \mathrm{M}+\mathrm{NM}$ 比は $\mathrm{A} / \mathrm{A}+\mathrm{NA}$ 比を夫々模倣する様な動きが見られたが，対照群と有意差を 示すのに至らなかつた，又 VMA 排泄には認むべき動きはなかつた。

尿中遊離型 CA 及び GA 代謝産物の pattern の差を論ずると，A+NA/VMA 比が CS 30日未満投与 群の昼間尿で，やや上昇の傾向を取る他は 30 日以上投与群及び就㷃時尿では差が認められず，又 $\mathrm{M}+\mathrm{MN} /$ VMA 比には 3 群を通じて，昼夜間尿共動きはなかつた，CS 投与を初めた初期には，MAO により intracellularly に代謝される部分に対し，活性型の遊離が増加する可能性があるとして，爾余は捉えうる程の偏 移はなく，CS は CA 遊離，代謝の面には直接的には，大きな影響を及ほささないと推定しうる。

CS 投与総量と尿中 CA 及び尿中 CA 代謝産物の動きについて検討を加えてみると（上記の 3 群の区分 は尚，便宜的であり，特に理論的なものではないが），尿中遊離型 A 排泄は，使用総量が可成りの量に達し ない内は, 一且上昇し, 後使用量か増加するにつれて減少する.NA には概して, 大きな変動はない。此 の結果は, 大略 CS 使用期間と尿中 CA 排泄の関係で得た絬果と相似である.

(3) CS 治療経過亡尿中 CA 排泄 (Table 2.)

3 例の入院患者について, betamethasone を, CS 治療開始より 21 日間 $3.0 \mathrm{mg}$ を，第 22 日より第 35 日の 14 日間 $2.0 \mathrm{mg}$ を，第 36 日以降 $1.5 \mathrm{mg}$ を投与しつつ，経日的に投与前 3 日間，投与中第 $7 ， 8 ， 9$ 日の 3 日間， 投与後第 40 日以降の 5 日間に採尿を行なつて，尿中 A，NA，17-OHCS を測定した。尿中 17-OHCS は CS 投与開始後著明に減少した，尿中 A は第 $7 ， 8 ， 9$ 日の 3 日間は增加の傾向を，第 40 日以下の 5 日間は低下 の傾向を示めした，尿中 NA は CS 投与後，特に投与の日の浅い第 $7 ， 8 ， 9$ 日の 3 日間は上昇の傾向を 取つた。 A/A+NA 比を取ると，第 7，8，9日では上旿し，第40〜44日では下降した。

（4）CS 投与中断後, 副腎皮質分泌恢復と尿中 CA 排泄量 (Table 3., Fig. 4.)

7 例の入院患者に betamethasone $3.0 \mathrm{mg}, 42$ 日間連用した後，4 日間中断し，4 日後再び投与を行ない， 中止前 2 日間，中断中 4 日間，再投与後 2 日間の計 8 日間の採尿を行ない，その間の尿中 $17-\mathrm{OHCS}$ の動 きと $\mathrm{CA}$ 尿中排泄の状態を観察した。

CS 中断前の 2 日間の尿中 17-OHCS は，全例共低值で，非投与対照群の值 $3.43 \pm 1.04 \mathrm{mg} /$ 日の下限を 割つたＣＣ～投与中断中， 7 例中 6 例は尿中 17-OHCS 排泄量の恢復を示し， 3 日目ないしは 4 日目に正常 域に入つた. 残る 1 例にも恢復の徴候はあつたが，その程度は弱く，対照群の域には至らなかつた。 CS 再 
Table 2. Changes of the urinary excretion of 17-OHCS and catecholamines, along the course of the steroids therapy.

Gase 1, 36 y.o., rheumatoidarthritis.

\begin{tabular}{l|c|c|c|c|c|c|c|c|c|c|c}
\hline & \multicolumn{3}{|c|}{ before CS therapy } & \multicolumn{6}{|c}{ days after beginning of CS therapy } \\
& 1. & 2. & 3. & 7. & 8. & 9. & 40. & 41. & 42. & 43. & 44. \\
\hline \hline A. ( $\mu$ g/day) & 5.11 & 5.02 & 4.55 & 7.69 & 4.81 & 8.19 & 4.00 & 3.50 & 3.81 & 2.99 & 3.56 \\
NA. ( $\mu$ g/day) & 31.5 & 26.6 & 38.9 & 40.0 & 25.8 & 45.9 & 33.0 & 40.0 & 29.9 & 30.1 & 40.0 \\
A./A.+NA. & 0.148 & 0.159 & 0.105 & 0.165 & 0.157 & 0.151 & 0.121 & 0.0804 & 0.113 & 0.0906 & 0.0802 \\
17-OGHS (mg/day) & 4.08 & 4.29 & 3.65 & 0.581 & 0.000 & 0.0200 & 1.29 & 1.58 & 0.551 & 2.01 & 1.00 \\
\hline
\end{tabular}

Gase 2, 54 y.o., serum hepatitis.

\begin{tabular}{l|c|c|c|c|c|c|c|c|c|c|c}
\hline & \multicolumn{3}{|c|}{ before CS therapy } & \multicolumn{6}{|c}{ days after beginning of CS therapy } \\
\hline & 1. & 2. & 3. & 7. & 8. & 9. & 40. & 41. & 42. & 43. & 44. \\
\hline A. $(\mu \mathrm{g} /$ day) & 3.12 & 2.87 & 4.00 & 5.24 & 6.61 & 4.05 & 2.10 & 1.89 & 2.54 & 2.22 & 1.56 \\
NA. $(\mu \mathrm{g} /$ day) & 25.6 & 20.1 & 26.6 & 30.0 & 35.2 & 31.0 & 22.0 & 18.9 & 29.0 & 19.6 & 20.5 \\
A./A.+ NA. & 0.109 & 0.125 & 0.131 & 0.131 & 0.158 & 0.116 & 0.087 & 0.0806 & 0.0875 & 0.102 & 0.0706 \\
17-OHCS (mg/day) & 2.61 & 2.00 & 3.36 & 3.36 & 0.789 & 0.996 & 0.681 & 0.0591 & 0.119 & 0.998 & 0.581 \\
\hline
\end{tabular}

Case 3, 35y.o., erythema nodosum.

\begin{tabular}{l|c|c|c|c|c|c|c|c|c|c|c}
\hline & \multicolumn{3}{|c|}{ before CS therapy } & \multicolumn{6}{c}{ days after beginning of CS therapy } \\
\hline & 1. & 2. & 3. & 7. & 8. & 9. & 40. & 41. & 42. & 43. & 44. \\
\hline \hline A. $(\mu \mathrm{g} /$ day) & 8.12 & 7.56 & 7.75 & 12.0 & 9.16 & 15.6 & 5.96 & 4.82 & 4.66 & 4.05 & 5.16 \\
NA. $(\mu \mathrm{g} /$ day) & 40.0 & 35.6 & 41.0 & 51.0 & 59.8 & 48.9 & 50.2 & 48.9 & 55.6 & 46.7 & 49.8 \\
A./A.+NA. & 0.169 & 0.175 & 0.159 & 0.190 & 0.133 & 0.308 & 0.106 & 0.0898 & 0.0773 & 0.0792 & 0.0938 \\
17-OHCS (mg/day) & 3.06 & 3.19 & 3.36 & 1.06 & 0.906 & 0.0876 & 1.10 & 0.586 & 1.55 & 0.596 & 0.991 \\
\hline
\end{tabular}

Daily urinary excretions of 17-OHCS and catecholamines were measured in 3 patients, for succeeding 3 days before CS therapy and on the 7., 8., 9., 40., 41., 42., 43. and 44. day after beginning of the therapy, respectively. Each patients were treated with betamethasone, for the first 21 days, $3.0 \mathrm{mg}$ daily, for next 14 days, $2.0 \mathrm{mg}$ daily and for the last 14 days, $1.5 \mathrm{mg}$ daily.

投与後, 全例尿中 17-OHCS は低下し, 非投与対照群の下限以下となつた。

他方 CS 投与中断前 2 日前の尿中 CA 排泄の 7 例の平均值及び標準偏差は，Aが $3.72 \pm 1.25 \mu \mathrm{g} /$ 日であ り，NA が $28.9 \pm 8.19 \mu \mathrm{g} /$ 日であり, 非投与対照群（A: $5.76 \pm 1.04 \mu \mathrm{g} /$ 日, NA : $30.4 \pm 10.3 \mu \mathrm{g} /$ 日）に対して, $\mathrm{A}$ は有意の低下 $(\mathrm{P}<0.005)$ を示し, NA は有意の差を示さなかつた. CS 中断後各例の尿中 CA 排泄は, 中断前に比へ殆ど変動を示さず，再投与に際しても変化がなかつた． 即ち，CS 長期投与により，副䐌皮質 が抑制され，A産生が低下，尿中排泄も低下する，CS 中断と共に $3 \sim 4$ 日後に副腎皮質分泌は恢復して来 るが，尿中 A 排泄には上昇を認めず，副腎髄質 $\mathrm{A}$ 産生の恢復は短期間では副緊皮質の恢復に追いつきえない と考えられる. (Fig. 4). 

物の尿中排泄に関する研究（池田）

Table 3. Influences of the interruption of the steroids therapy on the urinary excretion of 17-OHCS and catecholamines

\begin{tabular}{|c|c|c|c|c|c|c|c|c|}
\hline \multirow[t]{3}{*}{ Day on CS therapy } & \multicolumn{2}{|c|}{ before } & \multicolumn{4}{|c|}{$\begin{array}{l}\text { during the interruption of CS } \\
\text { therapy }\end{array}$} & \multicolumn{2}{|c|}{ readministration } \\
\hline & 1. & 2. & 3. & 4. & 5. & 6. & 7. & 8. \\
\hline & $\begin{array}{c}\mathrm{CS}, \\
3.0 \mathrm{mg} \\
41 \text { days } \\
\end{array}$ & $\begin{array}{c}\text { CS, } \\
3.0 \mathrm{mg} \\
42 \text { days } \\
\end{array}$ & $\mathrm{CS}(-)$ & CS $(-)$ & $\mathrm{CS}(-)$ & CS $(-)$ & $\begin{array}{l}\mathrm{GS}, \\
3.0 \mathrm{mg}\end{array}$ & $\begin{array}{l}\text { GS, } \\
3.0 \mathrm{mg}\end{array}$ \\
\hline \multirow{4}{*}{$\begin{array}{l}\text { Case 1. A. }(\mu \mathrm{g} / \text { day }) \\
\text { NA. ( } \mu \mathrm{g} / \text { day }) \\
\text { A./A.+NA. } \\
\text { 17-OHCS (mg/day) }\end{array}$} & 3.68 & 3.99 & 4.00 & 3.51 & 2.96 & 4.51 & 3.56 & 3.28 \\
\hline & 28.9 & 35.9 & 35.6 & 41.0 & 42.5 & 45.0 & 46.0 & 40.0 \\
\hline & 0.113 & 0.102 & 0.101 & 0.0789 & 0.0652 & 0.0911 & 0.0718 & 0.0758 \\
\hline & 0.0991 & 0.218 & 0.596 & 1.66 & 1.78 & 3.18 & 0.000 & 0.561 \\
\hline \multirow{4}{*}{$\begin{array}{c}\text { Gase } 2 . \text { A. }(\mu \mathrm{g} / \text { day }) \\
\text { NA. }(\mu \mathrm{g} / \text { day }) \\
\text { A./A. + NA. } \\
\text { 17-OHCS (mg/day) }\end{array}$} & 4.50 & 3.29 & 3.36 & 4.56 & 3.00 & 3.19 & 4.68 & 3.99 \\
\hline & 26.8 & 30.5 & 31.5 & 40.0 & 29.6 & 26.8 & 36.5 & 29.5 \\
\hline & 0.144 & 0.0976 & 0.0963 & 0.101 & 0.0900 & 0.106 & 0.114 & 0.119 \\
\hline & 1.56 & 0.580 & 2.81 & 3.31 & 5.06 & 4.48 & 1.66 & 1.00 \\
\hline \multirow{4}{*}{$\begin{array}{c}\text { Case 3. A. }(\mu \mathrm{g} / \text { day }) \\
\text { NA. ( } \mu \mathrm{g} / \text { day }) \\
\text { A./A. + NA. } \\
\text { 17-OHCS (mg/day) }\end{array}$} & 2.12 & 2.00 & 3.15 & 2.19 & 3.06 & 2.11 & 3.15 & 2.68 \\
\hline & 18.6 & 20.5 & 26.5 & 18.5 & 26.9 & 19.6 & 21.5 & 20.0 \\
\hline & 0.102 & 0.0889 & 0.106 & 0.100 & 0.102 & 0.0973 & 0.128 & 0.119 \\
\hline & 0.381 & 0.226 & 0.581 & 1.56 & 3.11 & 5.99 & 0.000 & 0.000 \\
\hline \multirow{4}{*}{$\begin{array}{c}\text { Gase 4. A. }(\mu \mathrm{g} / \text { day }) \\
\text { NA. }(\mu \mathrm{g} / \text { day }) \\
\text { A./A. + NA. } \\
\text { 17-OHCS (mg/day) }\end{array}$} & 5.00 & 4.98 & 5.16 & 4.46 & 3.29 & 4.96 & 6.96 & 5.11 \\
\hline & 31.5 & 30.6 & 26.8 & 30.6 & 22.9 & 26.8 & 29.0 & 45.0 \\
\hline & 0.137 & 0.140 & 0.158 & 0.127 & 0.126 & 0.156 & 0.189 & 0.102 \\
\hline & 0.0611 & 0.0800 & 0.0100 & 0.125 & 1.33 & 1.56 & 0.516 & 0.220 \\
\hline \multirow{4}{*}{$\begin{array}{l}\text { Case 5. A. ( } \mu \mathrm{g} / \text { day }) \\
\text { NA. ( } \mu \mathrm{g} / \text { day }) \\
\text { A. } / \text { A. + NA. } \\
\text { 17-OHGS (mg/day) }\end{array}$} & 5.39 & 4.00 & 3.89 & 2.11 & 3.16 & 4.68 & 5.61 & 3.09 \\
\hline & 36.9 & 28.9 & 40.9 & 36.0 & 29.1 & 26.0 & 29.0 & 48.0 \\
\hline & 0.127 & 0.122 & 0.0868 & 0.0554 & 0.0978 & 0.152 & 0.162 & 0.060 \\
\hline & 1.20 & 1.08 & 1.11 & 1.06 & 4.51 & 4.98 & 0.0510 & 0.362 \\
\hline \multirow{4}{*}{$\begin{array}{c}\text { Case 6. A. }(\mu \mathrm{g} / \text { day }) \\
\text { NA. }(\mu \mathrm{g} / \text { day }) \\
\text { A./A. }+ \text { NA. } \\
\text { 17-OHCS (mg/day) }\end{array}$} & 2.06 & 1.55 & 2.18 & 1.16 & 1.96 & 2.16 & 2.96 & 2.56 \\
\hline & 18.9 & 15.6 & 15.6 & 12.1 & 20.9 & 25.1 & 19.6 & 24.8 \\
\hline & 0.0981 & 0.0901 & 0.122 & 0.0872 & 0.0856 & 0.0791 & 0.131 & 0.0934 \\
\hline & 0.580 & 0.667 & 0.586 & 1.58 & 1.60 & 3.78 & 2.06 & 0.551 \\
\hline \multirow{4}{*}{$\begin{array}{l}\text { Gase 7. A. }(\mu \mathrm{g} / \text { day }) \\
\text { NA. }(\mu \mathrm{g} / \text { day }) \\
\text { A./A. + NA. } \\
\text { 17-OHCS (mg/day) }\end{array}$} & 3.33 & 3.14 & 3.65 & 2.08 & 3.16 & 2.99 & 2.19 & 2.98 \\
\hline & 41.3 & 36.9 & 28.5 & 40.0 & 30.5 & 29.0 & 26.4 & 25.6 \\
\hline & 0.0832 & 0.0785 & 0.114 & 0.0866 & 0.0938 & 0.0934 & 0.0766 & 0.104 \\
\hline & 0.550 & 0.660 & 1.29 & 1.83 & 2.90 & 3.35 & 1.16 & 2.06 \\
\hline
\end{tabular}

Daily urinary excretions of 17-OHCS and catecholamines were estimated in 7 patients. In each patient, CS treatments were continued for 42 days, with betamethasone, $3.0 \mathrm{mg}$ daily and then abruptly stopped. After the interruption for 4 days, therapy were reopened. Urine specimens were collected on the 41 . and the 42. day of the CS therapy, for 4 days during the interruption and the following 2 days of readministration. 
Fig. 4. Influences of the interruption of the steroids therapy on the urinary excretion of 17-OHCS and catecholamines. (means \& S.D. of the 7 cases)
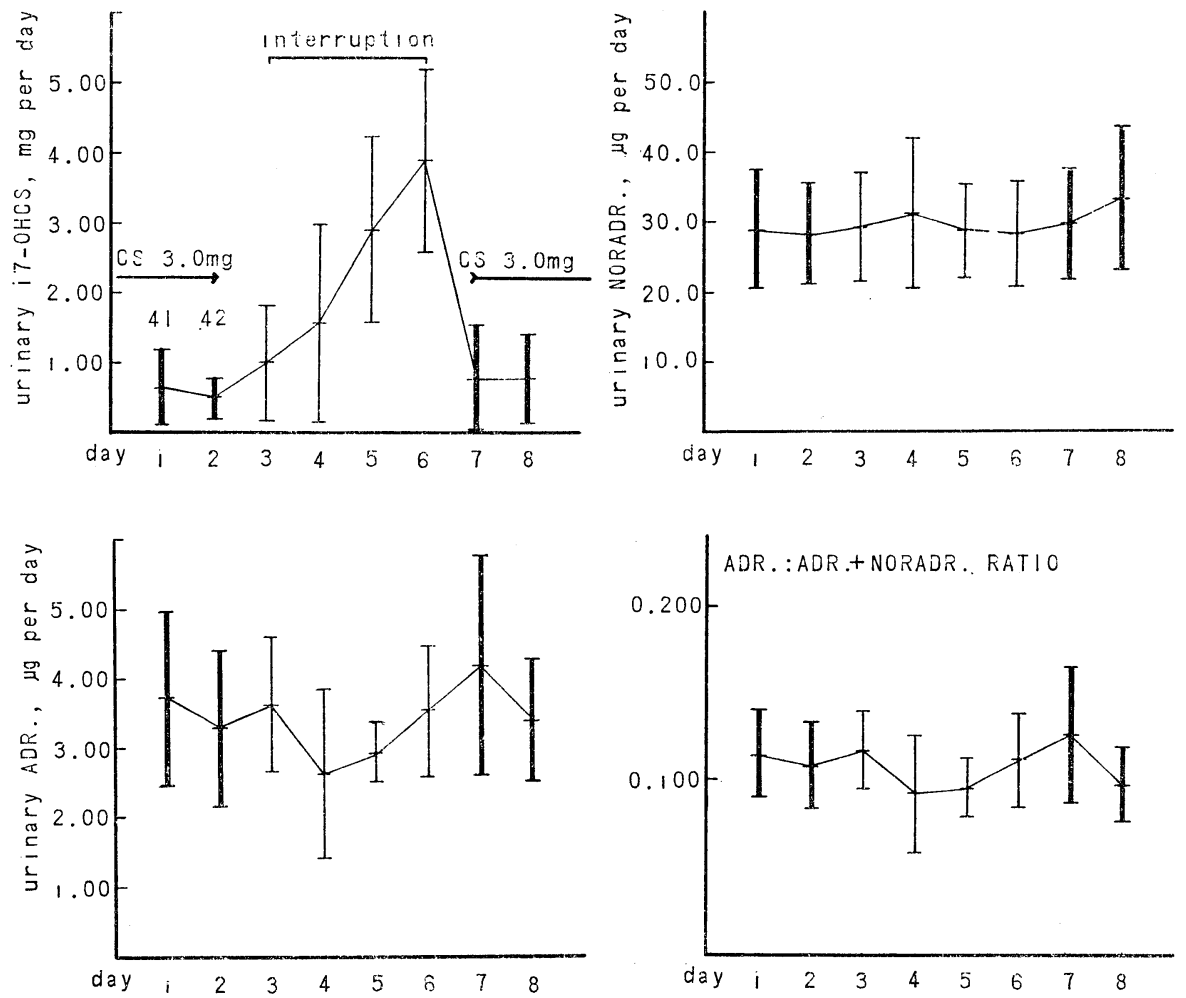

\section{総括及び考按}

West \& Shepherd $(1951)^{1)}$ やCoupland $(1953)^{12)}$ 亿より展開された副腎皮質と髄質の相互関係一皮質組 織とクロマヒン組織との解剖学的・位置的関係を通じて，皮質組織がクロマヒン組織中の NAより Aへの 転化に対し重要な因子を提供すると言う関係一が，Axerlod \& Wurtman ${ }^{3) ~ 8) ~}$ 等による一連の PNMT を中 心とした研究を通して具体的説明か泇えられた。彼等の提供した知見は諸方面の研究者の興味を㬇起し, 彼 等と平行，相前後して，多く研究対象として取り上げられ，理論の累積がなされて居る. 基礎医学の分野で 獲得された知識が単に基礎医学の分野のみに限定された興味や関心の充足に止まるととなく, 臨床医学の領 域にまで拡大されて行くなら理想的であり，動物実験を通じて得られた副腎皮質と蹃質の関係についての知 見が，人体について如何なる“かかわり”を有するか，今後に残された課題の一つとみてよい.

前述の如く, Wurtman ${ }^{7)}$ は正常ラットを用いた垁験で $10 \sim 100 \mu \mathrm{g} /$ 日の dexamethasone を 9 日間投与し， 副腎静脈内に流入する内因性 GS を抑制する事により，PNMT 活性の低下，㵦質内A含量の低下を誌め， 人体に於る CS 維持療法とA生合成の障害の可能性を示唆した。著者は此の提議に基ついて，純粋に臨床 的立場より，治療上 CS 投与を受けている患者を対象として尿中 CA 及び代謝産物の動きを観察してみた。 先ず現在 GS 治療中の患者群に対し, その治療のコースを無視して, 一律な GS 負荷をかける試みでは, CA の動きには一方向の傾向を得る事がなかつた。此の事は副腎皮質抑制による髄質 $\mathrm{A}$ 産生の変化の関係に は, 後述の如き皮質抑制の経過時間の問題が内在しているためであると考えられる. 即ち, 通常治療上使用 される程度の betamethasone, 1.5〜 4.0mg を連続投与すると，投与が短期間の内は（猶断定的でないが， 
$2 \sim 3$ 週の間は）髄質A分泌が光まり，投与がその期間を超えて続けられると逆に低下する．CS 投与に対

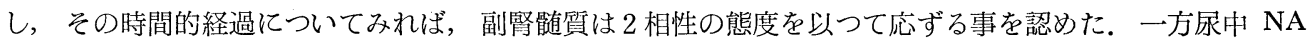
排泄は，CS 投与により本質的な影響は認められなかつた。人体では両側副腎剔除は尿中Aを急激かつ著明 飞低下せしめるが，尿中 NA 亿対しては殆ど変化を与光ない事実があり ${ }^{15)}$ (U.S. v. Euler その他，1954)， 尿中 NA は殆どが副㷂外性起源と考えうる。してみると CS 投与は㕼質外一交感神経末端には第一義的な 影響は有さないとみてよい，CS 投与時の尿中 CA 主要代謝産物排泄には有意の変化はなく，唯僅かに $\mathrm{M}$, NM に遊離型 A，NA の変化に追随するかの傾向をみた。尿中 O-methylated amine, VMA 排泄量の測 定では，CS の交感神経一副腎鹤質系及びその産生ホルモンの代謝系に与えるデリケイトな影響は捕捉され ないと言う疑念は残るが，ラットに於る実験では CS は CA 代謝系酵素, MAO, GOMT 亿対し影響を有 しない事か認められて居り ${ }^{6)}$ (Wurtman, 1966)，為に尿中 NM, VMA 排泄は著明な変化を示さないと考光 てよい，又，遊離型 $\mathrm{CA}: \mathrm{VMA}$, O-methylated amine : VMA の両者より GA 産生とその遊離の間の balance を考光てみたのであるが，極めて大雑把な意味では産生一遊雄の balance も崩れないと考学うる.

尿中 17-OHCS と尿中 CA との間には殆ど量的な対応関係は認められなかつた．CS 投与による副腎皮 質ホルモンの分泌の変化と，その変化により惹起される剈有質 $\mathrm{A}$ 産生の変化との間には機敏な相互の連携はな いため，量的な対応関係は成立しないと推定しうる。

実験の当初に於て，CS 総投与量と旤質 $\mathrm{A}$ 産生の変化の関係について dose-response curve の検討を目論 だのであるが，緻密な分析には猶例数が不満である。総投与量がある量に達しない間はAの分泌元進を見， その量を超すと㳹次低下する．NA は此較的変化がない，使用期間の投影と言うべき結果を得るに止まつ た.

以上著者の得た成績を判断すると，Axerlod \& Wurtman がラットに見た副腎皮質一㖪質の関係は人体 に於ても存在すると認めてよいと考光られるし，彼等の示唆の如く，外因性 CS に上る内因性 CS の抑制 により，髄質中A産生に変化を認めるとしてよいと考学られる，そてで臨床的に下垂体・副腎皮質機能障害 に於る副腎榷質一交感神経系機能を諭じた文献を参照してみると，成績は各研究者間で可成りマチマチの感 がある. Luft \& von Euler $(1956)^{16)}$ は下垂体剔除を受けた20例について，24時間尿中 CA 排泄を観察し， A, NA 排泄は下垂体剔除群と健常者群では相違しないし，1日 $25 \mathrm{mg}$ の投与量の cortisone は此の状態を 変えないとしている. Hung \& Migeon (1968) ${ }^{17)}$ は 2 才男児で AGTH 単独欠乏によると思われる低血糖症 の症例報告の中で，insulin 負荷試験による副腎髄質の反応性の減弱を報告し，Axerlod \& Wurtman の実 験に対する臨床的 analogue だと述べて居る. 唯此の場合 9 籄月の cortisone acetate 補償療法により，尿中 CA の基礎排泄は不変であるが，反応性は著明に増加しているとした事は唱逜質の機能維持には生理的量をは るかに超えた大量の CS が必要であると主張するAxerlod \& Wurtman の意見と合致しない面もある。我 国に於ては，藤沢 $(1970)^{18)}$ が Nelson 症候群，アシシンン氏病，シーハン症候群で，24時間尿中 CA の内, Aの占める比 $\mathrm{A} / \mathrm{CA}$ が低下していると述べており，一方中野等（1970) ${ }^{19)}$ は，汎下垂体機能低下症 8 例に 於て Aの排泄量は健康人と有意差を示さず，NA 值は減少傾向を示し，A対 NA 比は上昇する，又アシン ン氏病 6 例では，A尿中排泄は正常範囲にあるが，NA は明らかな高值を示し，A対 NA 比は下降したと 報告している。

同じく，CS 投与者の尿中 CA 排泄動態を論じた文献を造猟してみると矢張り，研究者により見解の一 致を見ない. Luft \& von Euler (1952) ${ }^{20)}$ はりウマチ様関節炎患者に, ACTH, Cortisone, desoxycorticosterone を投与して, ACTH, cortisone ではA排泄は不変で, NA 排泄の減少を認め, desoxycorticosterone では A, NA 共排泄量の変化を認めなかつた。 又管野 $(1965)^{9)}$ はりウマチ様関節炎，潰瘍性大腸炎，副婜 泩器症候群などの患者に predonisolone $10 \sim 15 \mathrm{mg} /$ 日， dexamethasone $0.5 \sim 3.0 \mathrm{mg} /$ 日を 4-55日に亘つ て投与し，尿中 $\mathrm{CA}$ ，総 $\mathrm{MN}, \mathrm{VMA}$ を測定した結果，それ等の排泄態度に一定の傾向を認めないと述べて

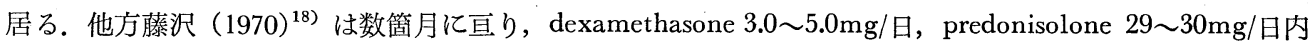
服した者で $\mathrm{A} / \mathrm{CA}$ 比は大きく変動して居るが，正常者に比し，低值の傾向があるとする， 
斯くの如くであり，動物実験の段階では Axerlod \& Wartman の説明による副腎皮質一髄質相互関係は 大した異論もなく，一般的に承認されて居るのであるが，臨床的に人体を対象とした場合には，動物実験で 確立された説との間にズレがあるばかりでなく，研究者相互にも見解の相違が生ずる．何故此の様なズレが 生ずるか，その原因を簡単に説明する事は困難であるが，中野 $(1970)^{19)}$ は生体に於ては，神経性，体液性 調節が複雑に関与しあつて, その成績も多彩で簡単に一定の傾向を引き出す事は困難であると述べて居る。

Neurotransmitter と stress hormone としての二者の性格を有する GA は前述の如く容易に生理的範囲 の刺激によつて大きく変動する。臨床的な立脚点より，ある疾患の病態生理を CA 生合成・分泌の面より 解明せんとする場合，その多くの場合予想される CA 分泌の偏移は生理的変動の巾をそう大きく超えるも のでないのが普通である，基本的な測定方法及び測定精度，被検者の選択及び管理，実験目的に対するアプ ローチの仕方等に於る諸研究者間の僅かの差が，結果を大きく引き離す事となる可能性がある.

動物実験では，下垂体剔除後可成り急速な副腎PNMT 活性低下に対し，㵦質内A含量の変化は遅延する 事が証明されて居る。Pochrecky \& Rust $(1968)^{21)}$ はラットの下垂体剔出後の副腎㖪質の変化を経日的に検 討しており，処置後㵦質内 PNMT 活性の低下は可成り急激で，4 日後約50\%の減少を示したのに対し，A 濃度の減少はずつと緩慢に術後 6 日目で変化なく，50日で50\%まで低下する事を観察して居る. 又島本，

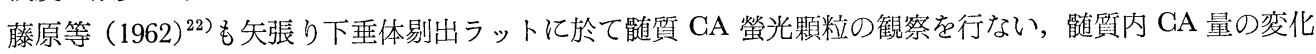
を追求しており, 術後 5 日以後皮質容量は減少, 日数経過と共にその程度は著しくなるのに反し, 髄質は少 なくとも20日経過するまで，A含有性と思われる細胞と NA 含有性と思われる細胞との 2 種の細胞群の螢 光性に明らかな変化を認めず，25日ないし38日に至つて，䯣質細胞の多くが黄褐色のNA 性細胞に変化す る事を認めた。同時に行なつた化学定量成績によると，NA 量は術後第27日に至るまで変動が小なるに対し， A量は第27日目に明らかに減少し，対応して A/GA 比が有意に低下した。以上の様に急性の下垂体副腎皮

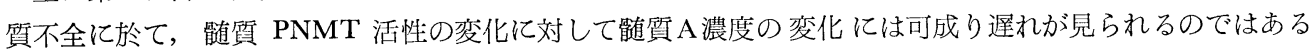
が，此の現象について島本・藤原（1968）はAの予備量が大であるのか，ACTH，CS の作用が長時間性で あるためと考光ており，Wurtman $(1966)^{6)}$ は下垂体剔除ラット髄質内Aの turnover の halftime は正常ラ ットの 7 日に対し，30〜80日と著明に延張している事実があり，下垂体剔除をすると PNMT 活性低下に より $\mathrm{A}$ 産生は低下するが, $\mathrm{A}$ 遊離分解の速度も抑制され, 産生, 分泌・分解の間飞新しい定常状態が生じ, その様な定常状態下で敬質細胞内の CA 濃度の変化に対する buffer action により急激な PNMT 活性 の低下に対し，A濃度の変化が緩慢であると推測して居る。いずれにしても尚上記の A濃度変化の遅延の mechanism に関しては推測の域を出ず，実験的証明は与えられていないが，下垂体剔出後約20日間の間は 㵦質内 $\mathrm{A}$ 濃度の変化は僅かであるとして誤りはないであろう。

鬼に角も，著者は通常量の betamethasone を投与されて居る患者では尿中 A 排泄量の動きが，投与開始 より一且上昇した後, ある期間をおいて初めて低下すると言う現象を見たのであるが，此の CS 投与開始 より，尿中 A排沘低下までの期間が，上記の如き動物実験の成續より考えて次の様に説明づけうるのでない であろうか. 即ち, CS 治療を施すと, 下垂体一副腎皮質は抑制され，髄質内 PNMT 活性は㓶合い急速に 低下するか浦道質内 $\mathrm{A}$ 含量が低下するのは可成り遅れ，ある期間後に至つて初めて相当著明となり，同時何 らかの機転で咀質細胞 $\mathrm{A}$ 遊出速度が抑制され，A生合成と $\mathrm{A}$ 分泌の新しい平衡関係が成立して尿中 $\mathrm{A}$ 排泄の 低下が認められると考无うる。しからば CS 投与早期に観察される尿中A排渄増加に対する説明であるが， 尚結論的な解釈は困難である。稲葉・中尾 $(1968)^{23)}$ は corticosterone はラット髄質細胞 CA の遊離を促 進するとしているが, CS 投与は副轳静脈内 CS を低下せしめるのであるから, 此の説に従うならば A分必 機能は抑制されていると考えうる。従つて此の早期のA排泄元進は CS 投与の䚙質細胞への直接的な働き かけではなく，CS の全身的な影響の間接的な反影とみてよいのであろうか. CS 投与の開始の早期に副作 用として, 精神的易興奮性, 睡眠障害等が挙げられるが此の様な精神的変化と関連付けて考えうる可能性も ある.

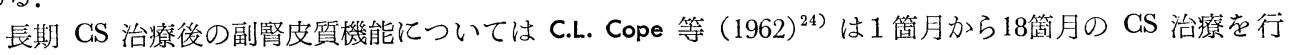


なつた患者で CS 投与中止後の 17-OHCS の動きを見ると，48時間以内に正常域に達し，中止後第 3 日目 の Cortisol secretion rate は正常值を示すと述べ，18笥月位の CS 治療では副腎皮質の恢復能力は障害さ れておらず，下垂体一副謷皮質系の機能は䛧在であると結諭して居る. 他方 Al. Graber 等 $(1965)^{25)}$ の研 究によると 1 〜 年生理量を超えて CS 療法を行なつた患者では, 中止後数筒月血清 AGTH は低く血清 17-OHCS も共に正常以下である。 その後 $1 \sim 4$ 箅月を経て，漸次血清 ACTH は正常化するが血清 17OHCS は正常以下の期間が尚持続し， 6 9 䉪月の間下垂体の ACTH 分泌が正常以上を持続する様になつ て初めて血清 17-OHCS が正常化して来る. 又西川 $(1962)^{26)}$ の詳細な観察によると, 中止後副腎分泌は 次第に強まり，3〜5 日頃に最高に達する.しかし此の增加は一過性で，その後間もなく減少し，以後長期 間低值を続ける。著者の betamethasone $3.0 \mathrm{mg}$, 42 日間連用後の中断でも, 尿中 17-OHCS は $3 \sim 4$ 日後に は正常域までの恢復が見られた．5 日以後は CS 再投与を行なつて，その後の観察は行なつていないが，上 記 Graber, 西川の成績から見ると, やがて再び低下が見られ, 多かれ少なか机低值を取る事が予想される. 所で CS 中止後に副腎皮質の方には前述の如き変動があるとして，投与中 2 日間，中断中 4 日間，再投与 2 日間の観察では尿中 CA の変動は殆ど示されず，低值の儘止まつた．前述の如く，副腎皮質が抑制を受 ける際, 対する㖪質中 $\mathrm{A}$ 含量の変化は可成り遅延して起る事を考察したのであるが, 副腎皮質機能恢復の際 にも， $\mathbf{A}$ 産生・分泌の障害の改善は皮質の動きと tie up せず可成り痋れると類推される。 下垂体剔出ラッ 卜に致死前 ACTH を投与した島本等 $(1968)^{22)}$ の実験では, ラットの体重増加が著明で副腎機能恢復が 認められるにも拘わらず, 副腎髄質螢光組織像は変化なく, 髄質 $\mathrm{A}$ 含量も増加が僅少であつた。しかし $\mathrm{ACTH}$ 投与が17日に及ぶとA増加が明らかになるという事が喼められて居る.

\section{結語}

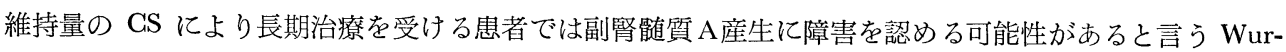
tman の提言に従つて臨床実験を試みた. CS 投与を受けて居る患者を選択して, その尿中 CA 及びその代 謝産物の排泄を観察した。尿中遊離型 NA，尿中 CA 代謝産物には CS 投与による影響を見るべき著明な 変化は捉えず，尿中遊離型Aに Wurtman の説を肯定すべき所見を見た．副腎皮質ホルモンと蹃質ホルモ ンの量的な相関関係，CS 投与量と髄質ホルモン分泌との間の dose-response relationship に関しても分析 を試みたが充分な結論を得るには尚より緻密な観察が必要である様である. 外因性 CS によつて副腎皮質が 抑制されると，尿中A排泄にも低下が見られる様になり，Wurtman の rat 亿於る知見は人体にも適応しう ると考えうる. しかし副腎皮質の抑制と尿中 A低下の出現には lag が見られ，初期には反つて尿中 A 一 且上昇する. 一方 CS 投与を解除すると $3 \sim 4$ 日以内に尿中 17-OHCS は復元して来, 副腎皮質の恢復を 窥わせるが，尿中 A は低值を取りつづけ，同様皮質の恢復と鹃質の恢復の際にも lag がある事を推定せし める. 此の lag についても文献を参照しながら若干の考察を試みた。

稿を終るに臨み，御指導御校閲をいただいた吉田秀雄教授に深謝致します。 本論文の要旨は第18回日本内分爫学会西部部会総会（昭和45年10月30日, 名古屋) で発表した.

\section{文献}

1) Shepherd, D.M. and West, G.B. : Brit. J. Pharmacol., $6: 66$, (1951).

2) Coupland, R.E. :

J. Endocr., 9 : 194, (1953).

3) Axerlod, J. : J. Biol. Chem., 237 : 1657, (1962).

Wurtman, R.J. and Axerlod, J. : Science, $150: 1464$, (1965).

5) Wurtman, R.J. and Axerlod, J. : J. Biol. Chem., $241: 2301$, (1966). 6) Wurtman. R.J : Endocrinol., 19 : 608, (1966).

7) Wurtman, R.J., Noble, E.P. and Axerlod, J. : Endocrinol., $80: 825$, (1967).

7) Wurtman,

R.J. and Axerlod, J. : Endocrinol., 80 : 815, (1967).

E.S. and Rass, G.T. : Endocrinol., 82 : 584, (1968).
8) Wurtman, R.J., Axerlod, J., Vessel, 9) Wurtman, R.J., Casper, A., Axerlod, J. 
and Bartter, F. : J. Clin. Invest., 46 : 1135, (1967).

11) Häggendal, J. : Acta physiol. Scand., $56: 258$, (1962).
10）菅野 泰：内科宝函，12：187，（1965）. 12) Sandler, M. and Ruthven,
G.R.J. : Biochem. J., 90 : 78, (1961). Physiol., 41 : 1387, (1968).

15) Kopin. J.J. : Pharmacol. Rev., 16 : 179, (1964).

Hallatrom, J. : Acta Physiol. Scand., 31 : 1, (1954).

13) Sankoff, J. and Sourkes, J.L. : Canad. J. Biochem. 14) Euler, U.S.v. : Glin. Pharmacol. Ther., 5 : 398, (1964). Endocr., 16 : 1017, (1956). 18) Hung, W. and Migeon, C.J. : J. Glin. Endocr., 28 : 146, (1968). 19）藤沢徹男：自律神経， $7: 164 ，(1970)$.

江崎 正, 菅野 泰: 最新医学, $25: 563$, (1970). 20）中野 裕, 新保慎一郎, 永山洋一, 真鍋 成, 21) Luft, R. and Euler, U.S.v. : Metabolism, $1: 179$, (1952). 22) Pohorecky, L. and Rust, J. H. : J. Pharmacol. Exp. Ther., 162 : 227, (1968). 23) 島本睴朗, 藤原元始 : 日内泌誌, $44: 611$, (1968).

24) 稲葉 稔, 中尾 健：日内泌誌, $44: 609$, (1968).

Med. J., $1: 1579$. (1962).

25) Robinson, B.H.B., Mattingly, D. and Cope, C.L. : Brit. : J. Glin. Endocr., $25: 11$, (1965). 26) Graber, A.L., Nicholson, W.E., Island, D.P. and Liddle, G.W. 27）西川光夫：日内会誌， $51 ： 69$, (1962). 